\title{
Glucocorticoid therapy does not delay viral clearance in COVID-19 patients
}

Jingjing $\mathrm{Ji}^{1+}$, Jinxia Zhang ${ }^{2 \dagger}$, Ziyun Shao ${ }^{3+}$, Qifeng $\mathrm{Xie}^{4 \dagger}$, Li Zhong ${ }^{5}$ and Zhifeng Liu ${ }^{1,6^{*}}$ (D)

Keywords: Glucocorticoid, COVID-19, Viral clearance

\section{Dear Editor,}

The coronavirus disease 2019 (COVID-19) outbreak has been a severe challenge worldwide. Accumulating evidence reveals that in COVID-19 patients, inflammatory cell infiltration and cytokine storm are key factors leading to acute lung injury and poor prognosis [1]. Glucocorticoid (GC) was one of the anti-inflammatory medications widely used in critically ill patients. Numerous clinical studies have reported the efficacy of GC in the treatment of coronavirus pneumonia; however, the use of GC in the treatment of critical COVID-19 cases is still controversial $[2,3]$. The main concern is that GC treatment may delay the clearance of virus. The current cohort study aimed to determine whether GC therapy would prolong the duration of SARS-CoV2 RNA shedding and SARS-CoV-2 clearance.

This cohort study analyzed clinical data from 684 adult patients with SARS-CoV-2 infections confirmed through RT-PCR on throat swab samples collected between January and March 2020 from two hospitals in Wuhan, China. All patients received standard treatment including antiviral and oxygen therapy, and symptomatic support. The demographic, laboratory data at admission and discharge, GC treatment, and prognosis of the patients were collected. During the treatment, the throat swab and/or sputum and/or lower respiratory tract samples from confirmed patients were collected and tested by RT-PCR every 2 to 3 days. For the severe and critical patients, the interval between two tests was 4 to 5 days. To avoid false negative results, only patients with three continuously negative tests were considered that they have viral RNA clearance. Therefore, for the patients with negative RT-PCR result, two more samples were collected in the following 2 days, respectively. Among the 684 cases, $202(29.5 \%)$ cases had viral RNA clearance within 14days after illness onset and 210 (30.7\%) cases had viral RNA clearance between 14 and 28 days, and 272 (39.8\%) cases had viral RNA clearance over 28 days. There were no differences on the age, gender, and underlying diseases between different groups. The degree of decrease in CD4 T cell and $B$ cell counts on admission was related with the prolonged viral RNA clearance (Table 1).

Since GC therapy was usually employed in critically ill patients, we analyzed the effect of GC therapy separately for patients with different severity. Patients were diagnosed as mild type, general type, severe type, and critical type according to the Chinese Recommendations for Diagnosis and Treatment of Novel Coronavirus (SARS-CoV-2) Infection (Trial 7th version) [4]. For the mild and general type patients, $30(6.1 \%)$ cases received

* Correspondence: Zhifengliu7797@163.com

${ }^{\dagger}$ Jingjing Ji, Jinxia Zhang, Ziyun Shao and Qifeng Xie contributed equally to this work.

'Department of Critical Care Medicine, General Hospital of Southern Theater Command of PLA, Guangzhou 510010, China

${ }^{6}$ Department of Critical Care Medicine, General Hospital of Southern Theater Command of PLA, Southern Medical University, Guangzhou 510010, China

Full list of author information is available at the end of the article 
Table 1 Demographics and laboratory data at admission of patients infected with COVID-19 according to the time to SARS-CoV-2 RNA clearance

\begin{tabular}{|c|c|c|c|c|c|}
\hline & Overall $(N=684)$ & $\leq 14$ days $(N=202)$ & $14-28$ days $(N=210)$ & $>28$ days $(N=272)$ & $p$ value \\
\hline \multicolumn{6}{|c|}{ Demographics, clinical characteristics } \\
\hline Age (years) & $61.0[49.0,70.0]$ & $62.0[48.0,71.0]$ & $60.5[49.3,70.0]$ & $61.5[51.0,70.3]$ & 0.733 \\
\hline Gender (\%) & & & & & 0.841 \\
\hline Male & $328(48.0)$ & $98(48.5)$ & $103(49.3)$ & $127(46.7)$ & \\
\hline Female & $355(52.0)$ & $104(51.5)$ & $106(50.7)$ & $145(53.3)$ & \\
\hline Clinical type (\%) & & & & & 0.009 \\
\hline Mild & $26(3.9)$ & $16(8.0)$ & $7(3.4)$ & $3(1.1)$ & \\
\hline General & $464(69.3)$ & $140(70.0)$ & $141(69.1)$ & $183(68.8)$ & \\
\hline Severe & $145(21.6)$ & $36(18.0)$ & $44(21.6)$ & $65(24.4)$ & \\
\hline Critical & $35(5.2)$ & $8(4.0)$ & $12(5.9)$ & $15(5.6)$ & \\
\hline Hypertension (\%) & $235(35.0)$ & $67(34.0)$ & $70(33.8)$ & $98(36.6)$ & 0.778 \\
\hline $\mathrm{CHD}(\%)$ & $75(11.2)$ & $22(11.2)$ & $25(12.1)$ & $28(10.4)$ & 0.855 \\
\hline CRF (\%) & $16(2.4)$ & $3(1.5)$ & $7(3.4)$ & $6(2.2)$ & 0.467 \\
\hline DM (\%) & $111(16.5)$ & $30(15.2)$ & $36(17.5)$ & $45(16.8)$ & 0.824 \\
\hline COPD (\%) & $13(1.9)$ & $3(1.5)$ & $3(1.4)$ & $7(2.6)$ & 0.588 \\
\hline Cirrhosis (\%) & $3(0.4)$ & $0(0.0)$ & $1(0.5)$ & $2(0.7)$ & 0.492 \\
\hline Stroke (\%) & $45(6.7)$ & $14(7.1)$ & $14(6.8)$ & $17(6.3)$ & 0.943 \\
\hline Tumor (\%) & $23(3.4)$ & $5(2.6)$ & $5(2.4)$ & $13(4.9)$ & 0.257 \\
\hline \multicolumn{6}{|c|}{ Inflammatory response, median (IQR) } \\
\hline CRP $(\mathrm{mg} / \mathrm{L})$ & $7.39[0.50,28.25]$ & $8.63[1.04,16.33]$ & $5.79[0.50,28.80]$ & $5.13[0.50,62.39]$ & 0.968 \\
\hline IL-6 (pg/mL) & $6.00[2.25,21.00]$ & $6.00[3.00,19.50]$ & $7.50[2.00,26.25]$ & $6.00[3.00,20.50]$ & 0.943 \\
\hline Fib (g/L) & $4.82[3.68,11.90]$ & $4.46[3.58,11.72]$ & $5.50[3.65,11.98]$ & $6.71[4.08,13.60]$ & 0.19 \\
\hline WBC $\left(10^{9} / L\right)$ & $5.59[4.46,7.06]$ & $5.60[4.47,6.79]$ & $5.51[4.52,7.12]$ & $5.33[4.38,7.83]$ & 0.962 \\
\hline Neutrophil $\left(10^{9} / \mathrm{L}\right)$ & $3.33[2.44,4.76]$ & $3.33[2.49,4.51]$ & $3.31[2.42,4.85]$ & $3.67[2.41,5.83]$ & 0.618 \\
\hline Monocyte $\left(10^{9} / \mathrm{L}\right)$ & $0.46[0.34,0.60]$ & $0.45[0.35,0.59]$ & $0.46[0.34,0.61]$ & $0.47[0.35,0.58]$ & 0.970 \\
\hline Lymphocyte $\left(10^{9} / \mathrm{L}\right)$ & $1.27[0.88,1.81]$ & $1.29[0.94,1.86]$ & $1.29[0.95,1.73]$ & $1.00[0.72,1.67]$ & 0.204 \\
\hline $\operatorname{PLT}\left(10^{9} / \mathrm{L}\right)$ & $203[158,249]$ & $209[156,267]$ & $196[158,241]$ & $189[148,244]$ & 0.209 \\
\hline $\mathrm{Hb}(\mathrm{g} / \mathrm{L})$ & $121[108,133]$ & $123[109,133]$ & $121[110,131]$ & $121[103,131]$ & 0.609 \\
\hline CD3 (count/ $\mu \mathrm{L}$ ) & $8905[474,1212]$ & $916[586,1220]$ & $705[423,1224]$ & $497[364,684]$ & 0.115 \\
\hline CD4 (count/ $\mu \mathrm{L}$ ) & $478[269,672]$ & $554[319,733]$ & $324[190,588]$ & $275[154,404]$ & 0.048 \\
\hline CD8 (count/ $\mu \mathrm{L})$ & $248[150,374]$ & $291[174,400]$ & $229[142,367]$ & $167[123,211]$ & 0.112 \\
\hline NK (count/ $\mu \mathrm{L})$ & $167[103,259]$ & $142[91.0,231]$ & $206[141,332]$ & $154[91.8,215]$ & 0.115 \\
\hline B cell (count/ $\mu \mathrm{L})$ & $175[104,281]$ & $195[131,296]$ & $187[91.0,279]$ & $94.0[72.8,126]$ & 0.030 \\
\hline \multicolumn{6}{|c|}{ Organ function measurement, median (IQR) } \\
\hline $\mathrm{ALT}(\mathrm{U} / \mathrm{L})$ & $27.0[18.0,41.0]$ & $26.0[18.0,40.5]$ & $29.0[19.0,43.0]$ & $27.0[18.3,38.3]$ & 0.679 \\
\hline AST (U/L) & $22.0[16.0,36.5]$ & $20.0[15.0,36.0]$ & $23.0[17.0,37.0]$ & $23.0[19.0,39.0]$ & 0.314 \\
\hline TBIL $(\mu \mathrm{mol} / \mathrm{L})$ & $11.2[8.40,14.0]$ & $11.3[8.7,14.0]$ & $11.0[8.30,13.0]$ & $11.1[8.53,15.8]$ & 0.731 \\
\hline $\mathrm{DBIL}(\mu \mathrm{mol} / \mathrm{L})$ & $2.80[2.10,3.70]$ & $2.70[2.20,3.60]$ & $3.00[1.92,3.68]$ & $2.90[1.90,4.40]$ & 0.935 \\
\hline Creatinine $(\mu \mathrm{mol} / \mathrm{L})$ & $61.0[50.0,75.0]$ & $61.0[50.0,78.5]$ & $60.0[50.2,74.7]$ & $60.0[50.2,72.5]$ & 0.694 \\
\hline $\mathrm{BUN}(\mathrm{mmol} / \mathrm{L})$ & $4.60[3.60,5.80]$ & $4.40[3.50,5.80]$ & $4.60[3.70,5.50]$ & $4.50[3.70,5.80]$ & 0.794 \\
\hline Lactate $(\mathrm{mmol} / \mathrm{L})$ & $1.10[1.00,1.35]$ & $1.00[0.90,1.30]$ & $1.10[1.00,1.30]$ & $1.10[1.00,1.60]$ & 0.395 \\
\hline Glucose (mmol/L) & $5.60[5.00,6.62]$ & $5.55[5.00,6.32]$ & $5.60[5.03,7.62]$ & $5.30[4.90,6.95]$ & 0.431 \\
\hline INR & $1.10[1.00,1.20]$ & $1.10[1.00,1.20]$ & $1.10[1.00,1.20]$ & $1.10[1.10,1.20]$ & 0.075 \\
\hline
\end{tabular}


Table 1 Demographics and laboratory data at admission of patients infected with COVID-19 according to the time to SARS-CoV-2 RNA clearance (Continued)

\begin{tabular}{|c|c|c|c|c|c|}
\hline & Overall $(N=684)$ & $\leq 14$ days $(N=202)$ & 14-28 days $(N=210)$ & $>28$ days $(N=272)$ & $p$ value \\
\hline CK (U/L) & $66.5[25.3,110.5]$ & $67.0[24.0,107.5]$ & $62.0[39.0,135.0]$ & $63.0[22.5,105.5]$ & 0.530 \\
\hline $\mathrm{BNP}(\mathrm{pg} / \mathrm{mL})$ & $67.9[28.0,152.3]$ & $67.9[28.0,243.0]$ & $62.0[27.0,126.0]$ & $97.0[41.5,128.8]$ & 0.490 \\
\hline NT-proBNP (pg/mL) & $745[88.0,1899]$ & $109[67.0,2679]$ & $1118[769.5,2237]$ & $745[382,859]$ & 0.532 \\
\hline GC treatment (\%) & $103(15.1)$ & $24(11.9)$ & $32(15.2)$ & $47(17.3)$ & 0.266 \\
\hline Methylprednisolone (\%) & $96(14.0)$ & $24(11.9)$ & $30(14.3)$ & $42(15.4)$ & 0.540 \\
\hline Dexamethasone (\%) & $12(1.8)$ & $2(1.0)$ & $3(1.4)$ & $7(2.6)$ & 0.392 \\
\hline Hydrocortisone (\%) & $1(0.1)$ & $0(0.0)$ & $0(0.0)$ & $1(0.4)$ & 0.468 \\
\hline \multicolumn{6}{|l|}{ Outcome } \\
\hline Hospital stay (days) & $25.0[16.0,38.0]$ & $21.0[14.0,28.0]$ & $24.0[18.0,32.0]$ & $37.0[21.0,47.0]$ & $<0.001$ \\
\hline Total course (days) & $45.0[33.0,59.3]$ & $30.0[19.5,39.5]$ & $41.0[32.0,54.0]$ & $57.0[47.0,67.0]$ & $<0.001$ \\
\hline Outcome (\%) & & & & & 0.414 \\
\hline Survival & $643(96.8)$ & $191(97.0)$ & $194(95.6)$ & $258(97.7)$ & \\
\hline Death & $21(3.2)$ & $6(3.0)$ & $9(4.4)$ & $6(2.3)$ & \\
\hline
\end{tabular}

GC treatment and 460 (93.1\%) cases did not. For the severe and critical type patients, $72(40 \%)$ cases were in the GC group and 108 (60\%) cases were in the non-GC group (Table 1). In this study, methylprednisolone was the most used glucocorticoid (Table 1) in a dose of $1-2 \mathrm{mg} /(\mathrm{kg}$.day) for 3 to 5 days according to the disease severity [4]. The results show that GC therapy increased hospital stay days but had no effect on the virus clearance time (Table 2). For the severe and critical patients, the median viral RNA clearance time in the GC group was 26 days (IQR $17-42$

Table 2 Effect of glucocorticoid on the outcome and inflammatory response on discharge of COVID-19 patients

\begin{tabular}{|c|c|c|c|c|c|c|}
\hline \multirow[t]{2}{*}{ Variables } & \multicolumn{3}{|c|}{ Mild and general group } & \multicolumn{3}{|c|}{ Severe and critical group } \\
\hline & Non-GC group & GC group & $p$ value & Non-GC group & GC group & $p$ value \\
\hline $\bar{N}$ & 460 & 30 & & 108 & 72 & \\
\hline Hospital stay (days) & $23.00[16.00,33.00]$ & $32.50[23.25,38.00]$ & 0.002 & $29.00[17.00,44.00]$ & $40.50[31.75,52.50]$ & $<0.001$ \\
\hline Viral RNA clearance (days) & $22.00[11.00,35.00]$ & $23.50[14.00,34.25]$ & 0.737 & $25.50[13.00,39.00]$ & $26.00[17.00,42.00]$ & 0.471 \\
\hline Total course (days) & $43.00[29.00,57.00]$ & $41.00[31.50,47.75]$ & 0.816 & $49.00[37.50,63.50]$ & $49.00[43.00,63.00]$ & 0.341 \\
\hline Outcome (\%) & & & 1 & & & 0.555 \\
\hline Survival & $446(99.8)$ & $30(100.0)$ & & $92(90.2)$ & $62(86.1)$ & \\
\hline Death & $1(0.2)$ & $0(0.0)$ & & $10(9.8)$ & $10(13.9)$ & \\
\hline \multicolumn{7}{|c|}{ Inflammatory response, median (IQR) } \\
\hline CRP (mg/L) & $2.93[0.90,10.00]$ & $4.15[2.04,10.50]$ & 0.378 & $3.19[0.77,21.20]$ & $4.59[1.16,13.15]$ & 0.457 \\
\hline IL-6 (pg/mL) & $3.00[2.00,7.00]$ & $5.00[2.00,12.50]$ & 0.253 & $16.00[4.75,36.00]$ & $9.50[7.25,32.00]$ & 0.986 \\
\hline Fib (g/L) & $3.58[2.78,4.84]$ & $3.96[3.58,11.43]$ & 0.227 & $3.53[2.84,14.39]$ & $3.90[3.60,10.90]$ & 0.275 \\
\hline WBC $\left(10^{9} / L\right)$ & $5.55[4.40,6.55]$ & $5.20[4.25,6.08]$ & 0.568 & $5.93[5.00,7.50]$ & $6.80[4.90,8.55]$ & 0.485 \\
\hline Neutrophil $\left(10^{9} / \mathrm{L}\right)$ & $3.17[2.49,4.04]$ & $3.05[2.25,3.98]$ & 0.641 & $3.76[2.85,5.20]$ & $4.79[3.09,6.80]$ & 0.178 \\
\hline Monocyte $\left(10^{9} / \mathrm{L}\right)$ & $0.46[0.36,0.57]$ & $0.49[0.41,0.66]$ & 0.177 & $0.43[0.35,0.66]$ & $0.51[0.40,0.63]$ & 0.311 \\
\hline Lymphocyte $\left(10^{9} / \mathrm{L}\right)$ & $1.56[1.25,1.91]$ & $1.47[1.23,1.88]$ & 0.801 & $1.21[0.97,1.79]$ & $1.10[0.85,1.55]$ & 0.207 \\
\hline $\operatorname{PLT}\left(10^{9} / \mathrm{L}\right)$ & $209.0[173.0,258.0]$ & $212.0[183.8,266.5]$ & 0.923 & $212.0[151.0,236.0]$ & $183.0[144.0,250.0]$ & 0.615 \\
\hline $\mathrm{Hb}(\mathrm{g} / \mathrm{L})$ & $128.5[117.25,138.8]$ & $133.0[127.0,137.0]$ & 0.667 & $117.5[102.5,129.0]$ & $119.0[100.0,125.0]$ & 0.669 \\
\hline CD3 (count/ $\mu \mathrm{L})$ & $1144[861,1293]$ & $1002[793,1282]$ & 0.791 & $509[162.0,1026]$ & $683.5[478.8,1112]$ & 0.508 \\
\hline CD4 (count/ $\mu \mathrm{L})$ & $625.0[514.0,831.5]$ & $498.0[385.0,801.0]$ & 0.442 & $306.0[65.3,585.5]$ & $338.5[257.5,547.0]$ & 0.449 \\
\hline CD8 (count/ $\mu \mathrm{L})$ & $357.0[246.0,454.0]$ & $364.0[248.5,478.5]$ & 0.845 & $133.0[72.3,341.5]$ & $257.0[190.3,389.3]$ & 0.257 \\
\hline NK (count/ $\mu \mathrm{L})$ & $201.0[128.0,271.5]$ & $90.0[55.0,132.0]$ & 0.008 & $52.5[40.0,124.00]$ & $93.50[62.5,117.3]$ & 0.257 \\
\hline B cell (count/pL) & $171.0[132.5,265.0]$ & $248.0[146.0,328.5]$ & 0.493 & $68.5[58.5,126.8]$ & $115.0[94.3,156.0]$ & 0.299 \\
\hline
\end{tabular}


days), while the viral RNA clearance time in the non-GC group was 25.5 days (IQR 13-39 days). In addition, the GC treatment had no effect on the peripheral lymphocyte counts, including CD4 T cells, CD8 T cells, NK cells, and B cells (Table 2).

The current multicenter cohort study demonstrates that GC therapy does not change viral clearance and peripheral lymphocyte counts in COVID-19 patients. However, well-designed and large-scale randomized controlled trials are needed to further confirm the results derived from this observational study.

\section{Acknowledgements}

We thank the help from Zheying Liu and Conglin Wang during the data collection, and thank Jie Fan (University of Pittsburgh, USA) for revising the manuscript.

\section{Authors' contributions}

All authors had full access to all the data in the study and take responsibility for the integrity of the data and the accuracy of the data analysis. Zhifeng Liu was responsible for the study concept and design. Jinxia Zhang, Ziyun Shao, Qifeng Xie, and Li Zhong were responsible for collecting the data. Jingjing Ji, Jinxia Zhang, and Ziyun Shao were responsible for the statistical analysis. Jingjing Ji was responsible for drafting the manuscript. All authors commented on the previous versions of the manuscript. All authors read and approved the final manuscript

\section{Funding}

This work was supported by grants from the PLA Logistics Research Project of China [18CXZ030, 17CXZ008]. The funder of the study had no role in study design, data collection, data analysis, data interpretation, or writing of the report. The corresponding author had full access to all the data in the study and had final responsibility for the decision to submit for publication.

\section{Availability of data and materials}

The datasets used and/or analyzed during the current study are available from the corresponding author on reasonable request.

\section{Ethics approval and consent to participate}

The study was approved by the Research Ethics Commission of General Hospital of Southern Theater Command of PLA. The requirement for informed consent was waived by the Ethics Commission.

\section{Consent for publication}

All authors reviewed the manuscript and approved the publication.

\section{Competing interests}

The authors declare that they have no competing interests.

\section{Author details}

'Department of Critical Care Medicine, General Hospital of Southern Theater Command of PLA, Guangzhou 510010, China. ${ }^{2}$ Cardiovascular Department, General Hospital of Southern Theater Command of PLA, Guangzhou 510010, China. ${ }^{3}$ Department of Nephrology, General Hospital of Central Theater Command of PLA, Wuhan 430070, China. ${ }^{4}$ Department of Urology Surgery, General Hospital of Southern Theater Command of PLA, Guangzhou 510010, China. ${ }^{5}$ Department of Critical Care Medicine, The First Affiliated Hospital, Guizhou University of Chinese Medicine, Guiyang 550001, China.

${ }^{6}$ Department of Critical Care Medicine, General Hospital of Southern Theater Command of PLA, Southern Medical University, Guangzhou 510010, China.

Received: 17 July 2020 Accepted: 14 September 2020

Published online: 21 September 2020

\section{References}

1. Zhang W, Zhao Y, Zhang F, Wang Q, Li T, Liu Z, et al. The use of antiinflammatory drugs in the treatment of people with severe coronavirus disease 2019 (COVID-19): the perspectives of clinical immunologists from China. Clin Immunol. 2020;214:108393.

2. Fang $X$, Mei Q, Yang T, Li L, Wang Y, Tong F, et al. Low-dose corticosteroid therapy does not delay viral clearance in patients with COVID-19. J Infect. 2020;81(1):1472020;133(9):1039-78.

3. Ling Y, Xu S-B, Lin Y-X, Tian D, Zhu Z-Q, Dai F-H, et al. Persistence and clearance of viral RNA in 2019 novel coronavirus disease rehabilitation patients. Chin Med J. 2020;133(9):1039-43.

4. National Health Commission of the People's Republic of China. Chinese recommendations for diagnosis and treatment of novel coronavirus (SARS CoV2) infection (Trial 7th version). 2020.

\section{Publisher's Note}

Springer Nature remains neutral with regard to jurisdictional claims in published maps and institutional affiliations.
Ready to submit your research? Choose BMC and benefit from:

- fast, convenient online submission

- thorough peer review by experienced researchers in your field

- rapid publication on acceptance

- support for research data, including large and complex data types

- gold Open Access which fosters wider collaboration and increased citations

- maximum visibility for your research: over $100 \mathrm{M}$ website views per year

At BMC, research is always in progress.

Learn more biomedcentral.com/submission 